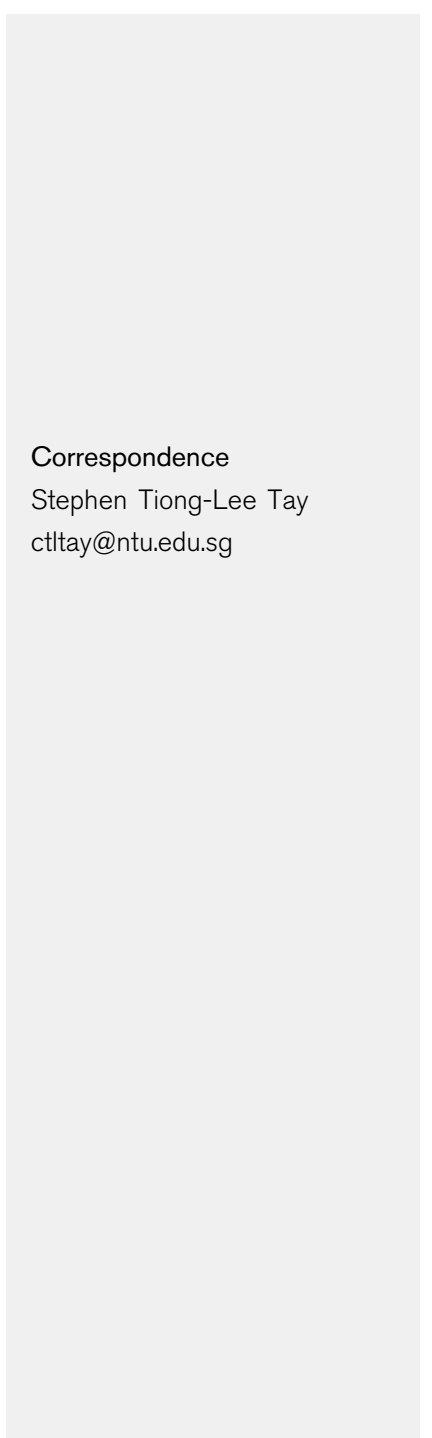

\title{
Quadrisphaera granulorum gen. nov., sp. nov., a Gram-positive polyphosphate-accumulating coccus in tetrads or aggregates isolated from aerobic granules
}

\author{
Abdul Majid Maszenan, ${ }^{1}$ Joo-Hwa Tay, ${ }^{1}$ Peter Schumann, ${ }^{2}$ He-Long Jiang ${ }^{1}$ \\ and Stephen Tiong-Lee Tay ${ }^{1}$
}

${ }^{1}$ Environmental Engineering Research Centre, School of Civil and Environmental Engineering,
Nanyang Technological University, 50 Nanyang Avenue, \#N1-01a-09, Singapore 639798

${ }^{2}$ DSMZ - Deutsche Sammlung von Mikroorganismen und Zellkulturen GmbH, D-38124 Braunschweig, Germany

\begin{abstract}
A Gram-positive bacterium, designated strain $\mathrm{AG019}{ }^{\top}$, was isolated by micromanipulation from aerobic granules obtained from a laboratory-scale sequencing batch reactor. This isolate grew axenically as cocci clustered predominantly in tetrads, and was morphologically similar to the dominant organisms observed in the biomass. The morphology also resembled that of the tetrad-forming organisms commonly seen in activated sludge samples. Strain AG019 ${ }^{\top}$ was found to be an oxidase-negative, catalase-positive, non-motile aerobe that does not reduce nitrate and grows at temperatures between 15 and $40{ }^{\circ} \mathrm{C}$, with an optimum at $37^{\circ} \mathrm{C}$. The $\mathrm{pH}$ range for growth was 5.0-9.0, with an optimum at $\mathrm{pH} 7 \cdot 5$. Strain $\mathrm{AG}^{\circ} 19^{\top}$ contained a peptidoglycan with directly cross-linked meso-diaminopimelic acid (type $A 1 \gamma$ ) and lacked mycolic acids. The $\mathrm{G}+\mathrm{C}$ content of the DNA was $75 \mathrm{~mol} \%$. Menaquinone $\mathrm{MK}-8\left(\mathrm{H}_{2}\right)$ was the major isoprenoid quinone. The bacterium stained positively for intracellular polyphosphate granules but not for poly- $\beta$-hydroxyalkanoates. It produced capsular material and showed autoaggregation ability. Phenotypic and 16S rRNA gene analyses showed that the bacterium differed sufficiently from its closest phylogenetic relatives, namely members of the suborder Frankineae, which includes the genera Geodermatophilus, Blastococcus, Frankia, Sporichthya, Acidothermus and Microsphaera, that it is proposed that it be placed in a novel genus, Quadrisphaera, as Quadrisphaera

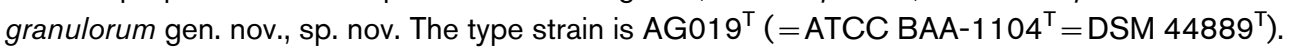

The occurrence of coccoid bacteria with a distinctive tetrad morphology first surfaced in activated sludge systems in the early 1990s (Cech \& Hartman, 1990). These were Gramnegative cocci and were commonly seen in reactors fed with an acetate/glucose mixture. Since then, tetrad-forming organisms (TFOs) with a similar morphological description have been reported in other activated sludge systems. These organisms belong to several novel genera that span both the Gram-positive and Gram-negative lineages (Maszenan, 2000; Seviour et al., 2000; Tsai \& Liu, 2002).

Published online ahead of print on 15 April 2005 as DOI 10.1099/ ijs.0.63583-0.

Abbreviation: TFO, tetrad-forming organism.

The GenBank/EMBL/DDBJ accession number for the 16S rRNA gene sequence of strain $A G 019^{\top}$ is $A Y 831385$.

Tables comparing the signature nucleotides of the 16S rRNA gene for the suborder Frankineae and strain $\mathrm{AG019}^{\top}$ are available as supplementary data in IJSEM Online.
TFOs have also been detected during routine microscopic examination of aerobically grown microbial granules cultivated in a laboratory-scale sequencing batch reactor (Dulekgurgen et al., 2003). Aerobic granules are a recent innovation in biological wastewater treatment and are selfimmobilized aggregates of bacteria with a strong and compact structure, good settling ability, high biomass retention and an ability to handle high organic loading rates (Moy et al., 2002). The granules are also metabolically versatile, have been cultivated on different biodegradable organic substrates (Jiang et al., 2002, 2004; Moy et al., 2002; Pan et al., 2004; Tay et al., 2001) and are capable of nitrification, denitrification and polyphosphate accumulation (Dulekgurgen et al., 2003; Jang et al., 2003; Lin et al., 2003; Tay et al., 2002; Zeng et al., 2003).

This paper describes the characterization of a Gram-positive TFO, designated strain $\mathrm{AG} 019^{\mathrm{T}}$, isolated from aerobic granules. The results of phenotypic and phylogenetic 
analyses support the classification of strain $\mathrm{AG}_{019^{\mathrm{T}}}$ as a novel genus within the family Frankiaceae.

The aerobic granules were cultivated in a laboratory-scale sequencing batch reactor as described previously, with synthetic wastewater containing acetate as the sole carbon source (Moy et al., 2002). Granule samples were harvested 4 weeks after reactor startup, and were disrupted at 2500 r.p.m. for 3 min with a Mini Beadbeater (Biospec Products). Microscopic observations (BX60 apparatus; Olympus) of these granules revealed that the microbial community was dominated by coccoid cells that clustered mostly in tetrads. These coccoid cells were retrieved from the disintegrated biomass using a Skerman micromanipulator (Skerman, 1968) and transferred to GS agar (Williams \& Unz, 1985) plates for incubation at $25^{\circ} \mathrm{C}$ (Williams \& Unz, 1985). Colonies arising from micromanipulated cells were transferred several times to GS agar plates to obtain pure cultures; culture purity was confirmed microscopically (BX60; Olympus) by examining cells from single colonies. An axenic culture of strain $\mathrm{AG} 019^{\mathrm{T}}$ was preserved at $-80^{\circ} \mathrm{C}$ in GS medium (Williams \& Unz, 1985) containing $20 \%$ glycerol.

Strain $\mathrm{AG} 019^{\mathrm{T}}$ possessed the distinctive morphology of TFOs, i.e. cocci arranged in tetrads or clusters (Fig. 1). Strain AG019 ${ }^{\mathrm{T}}$ was slow-growing and took 7 days to appear as visible colonies on a GS agar plate; it was probably an aerobe, as no growth occurred down the line of inoculation in stab culture. The strain grew at temperatures between 15 and $40^{\circ} \mathrm{C}$, with an optimum at $37^{\circ} \mathrm{C}$, and grew at $\mathrm{pH}$ values between $5 \cdot 0$ and $9 \cdot 0$, with an optimum at $\mathrm{pH} 7 \cdot 5$. The cells stained Gram-positive with the modified Gram-stain method of Hucker (Smibert \& Krieg, 1994); this was also confirmed by the absence of stringiness with $3 \% \mathrm{KOH}$ treatment (Buck, 1982). No flagella were detected, and the motility test indicated that strain $\mathrm{AG} 019^{\mathrm{T}}$ was non-motile.

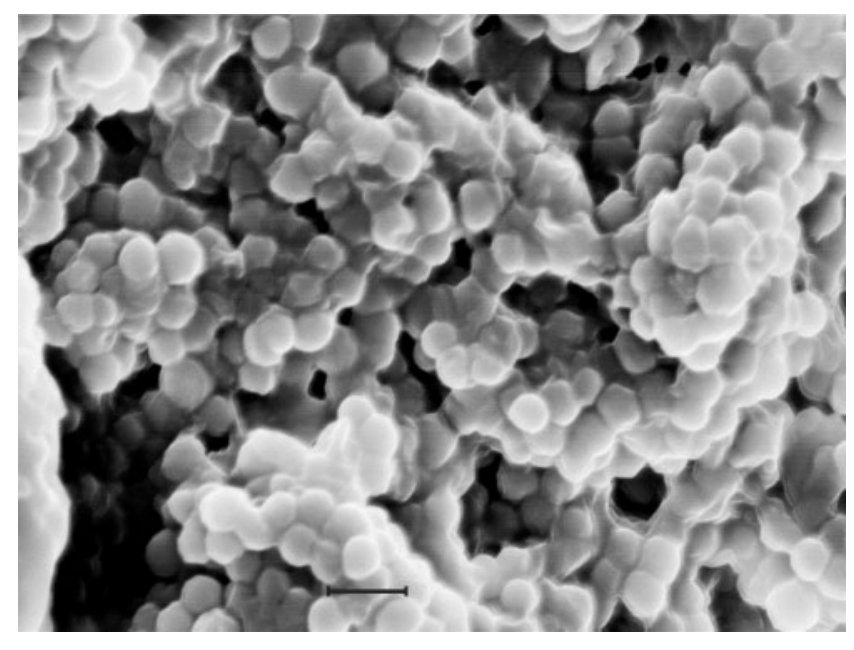

Fig. 1. Scanning electron micrograph of strain $A G 019^{\top}$ showing cocci in tetrad and cluster arrangement. Bar, $3 \mu \mathrm{m}$.
Polyphosphate granules were observed when cells were grown aerobically with glucose, acetate or propionate as the sole carbon source, but polyhydroxyalkanoate granules were not detected when cells were grown anaerobically using the dual staining method of Rees et al. (1992). No endospores were detected. Capsular materials were observed with the Indian ink stain (Difco).

A flocculation assay was performed on strain $\mathrm{AG} 019^{\mathrm{T}}$, as described previously (Malik et al., 2003). Strain AG019 ${ }^{\mathrm{T}}$ was inoculated into $200 \mathrm{ml} \mathrm{GS}$ medium, then incubated at $20^{\circ} \mathrm{C}$ with shaking at 100 r.p.m. The optical density (OD) of the mixed suspension was measured at a wavelength of $600 \mathrm{~nm}$ as initial $\mathrm{OD}\left(\mathrm{OD}_{\text {initial }}\right)$. The cell suspension was allowed to stand at $20^{\circ} \mathrm{C}$, then the supernatant layer was carefully pipetted at different standing times for OD measurement. The aggregation index was calculated on the basis of the OD value $\left(\mathrm{OD}_{t}\right)$ at a predefined standing time $(t)$, as follows:

Aggregation index $(\%)=\frac{\mathrm{OD}_{\text {initial }}-\mathrm{OD}_{t}}{\mathrm{OD}_{\text {initial }}} \times 100$

Flocculation-assay results showed that strain $\mathrm{AG} 019^{\mathrm{T}}$ had high autoaggregation ability. The aggregation index reached $25 \%$ after a standing time of between 150 and $210 \mathrm{~min}$.

The physiological and biochemical characteristics of strain $\mathrm{AG} 019^{\mathrm{T}}$ are presented in the descriptions of the genus and species. Enzyme profiles and biochemical characteristics of strain $\mathrm{AG} 019^{\mathrm{T}}$ were determined using the API ZYM and API 20E systems according to the manufacturer's instructions (bioMérieux). Carbon-substrate utilization tests were performed with the Biolog GN and GP systems (Special Diagnostics). The cells were catalase-positive but oxidaseand urease-negative, as determined by the method of Smibert \& Krieg (1994). The G $+\mathrm{C}$ content of the genomic DNA was $75 \mathrm{~mol} \%$, as determined by using the reverse HPLC method (Schumann et al., 1997).

The peptidoglycan, menaquinone, cellular fatty acid and polar lipid compositions were analysed as described by Schumann et al. (1997). Strain AG019 ${ }^{\mathrm{T}}$ possessed type A $1 \gamma$ peptidoglycan with meso-diaminopimelic acid as the diagnostic diamino acid (Schleifer \& Kandler, 1972). The cells lacked mycolic acid, but contained four isoprenoid quinones, MK- $8\left(\mathrm{H}_{2}\right)$, MK-7 $\left(\mathrm{H}_{2}\right)$, MK-6 $\left(\mathrm{H}_{2}\right)$ and MK$9\left(\mathrm{H}_{2}\right)$, in the ratio $88: 3: 2: 1$. The polar lipids present included diphosphatidylglycerol, phosphatidylglycerol and phosphatidylinositol; the cellular fatty acid profiles of strain AG019 ${ }^{\mathrm{T}}$ were dominated by 12 -methyl tetradecanoic acid and hexadecanoic acid (Table 1).

The almost-complete 16S rRNA gene of strain $\mathrm{AG} 019^{\mathrm{T}}$ was amplified and sequenced using methods described previously (Maszenan et al., 1997). A sequence of 1403 nucleotide bases was obtained in both directions, corresponding to positions 20-1471 of Escherichia coli according to the nomenclature of Winker \& Woese (1991), and was manually aligned against reference sequences of close relatives by 
Table 1. Cellular fatty acid composition of strain AG019

\begin{tabular}{|lc|}
\hline Cellular fatty acid composition & Content (\%) \\
\hline Tetradecanoic acid $\left(\mathrm{C}_{14: 0}\right)$ & $3 \cdot 2$ \\
13-Methyl tetradecanoic acid $\left(\mathrm{i}-\mathrm{C}_{15: 0}\right)$ & $4 \cdot 0$ \\
12-Methyl tetradecanoic acid $\left(\right.$ ai- $\left.\mathrm{C}_{15: 0}\right)$ & $56 \cdot 7$ \\
Pentadecanoic acid $\left(\mathrm{C}_{15: 0}\right)$ & $3 \cdot 6$ \\
14-Methyl pentadecanoic acid (i- $\left.\mathrm{C}_{16: 0}\right)$ & $4 \cdot 1$ \\
Hexadecanoic acid $\left(\mathrm{C}_{16: 0}\right)$ & $14 \cdot 9$ \\
15-Methyl hexadecanoic acid (i- $\left.\mathrm{C}_{17: 0}\right)$ & $2 \cdot 2$ \\
14-Methyl hexadecanoic acid (ai- $\left.\mathrm{C}_{17: 0}\right)$ & $4 \cdot 1$ \\
cis-Octadecanoic acid $\left(\mathrm{C}_{18: 1}\right)$ & $5 \cdot 6$ \\
\hline
\end{tabular}

using the alignment editor in BioEdit (Hall, 1997). Sequence analysis was performed using BLAST (Altschul et al., 1997), CLUSTAL W (Thompson et al., 1994), SIMILARITY_ RANK and SUGGEST_TREE in the Ribosomal Database Project, version 8.0 (Maidak et al., 1997). Distance analysis was performed on a final dataset that contained an unambiguous alignment of 1314 bases of strain $\mathrm{AG} 019^{\mathrm{T}}$ and its closest relatives. A phylogenetic tree was constructed from evolutionary distances by using the FITCH program in PHYLIP (Felsenstein, 1985). Bootstrap confidence values were obtained with 100 resamplings.

To our knowledge, this is the first study to use micromanipulation on aerobic granules for isolating TFOs. Conventional isolation techniques such as serial dilution and the spread-plate method have a low success rate for the isolation of TFOs because these micro-organisms grow slowly, and fast-growing bacterial cells often outgrow them (Maszenan, 2000; Seviour et al., 2000). Previous studies of
TFOs in activated sludge systems have resulted in the isolation of several novel genera of the Actinobacteria, some of which are thought to play a major role in biological phosphorus removal in activated sludge plants (Christensson et al., 1998; Seviour et al., 2000). Strain AG019 ${ }^{\mathrm{T}}$ stained positively for polyphosphate when grown under aerobic conditions using either glucose or acetate as the sole carbon source, but no polyhydroxyalkanoate accumulation was observed under anaerobic conditions with acetate. Flocculation studies also show that strain AG019 ${ }^{\mathrm{T}}$ can autoaggregate with an aggregation index of $25 \%$ after $120 \mathrm{~min}$. The ability both to autoaggregate and synthesize capsular material might confer on strain $\mathrm{AG} 019^{\mathrm{T}}$ a selective advantage over other bacteria in aerobic granular sludge systems in allowing them to overcome cell washout and thus remain in the reactor, and also to avoid predation from bacteria scavengers such as ciliates and protozoa (Cech et al., 1994; Seviour et al., 2000).

Analysis of the $16 \mathrm{~S}$ rRNA gene from strain $\mathrm{AG} 019^{\mathrm{T}}$ revealed that it is a member of the Gram-positive bacteria in the high$\mathrm{G}+\mathrm{C}$-content group Actinobacteria classis nov. in the domain Bacteria (Stackebrandt et al., 1997). Pairwise comparison of $16 \mathrm{~S}$ rRNA gene sequences revealed that strain $\mathrm{AG} 019^{\mathrm{T}}$ was $95 \%$ similar to Kineococcus-like bacteria and Sporichthya, $93 \%$ similar to the type strain of Kineococcus aurantiacus, less than $94 \%$ similar to members of the genera Frankia and Blastococcus, and $93 \%$ similar to members of the genera Acidothermus, Geodermatophilus and Microsphaera, as shown in Fig. 2. Strain $\mathrm{AG}_{01}{ }^{\mathrm{T}}$ is related to members of the genus Microsphaera (Yoshimi et al., 1996), which belongs to the suborder Frankineae. However, strain $\mathrm{AG} 019^{\mathrm{T}}$ is different from the other TFOs in the

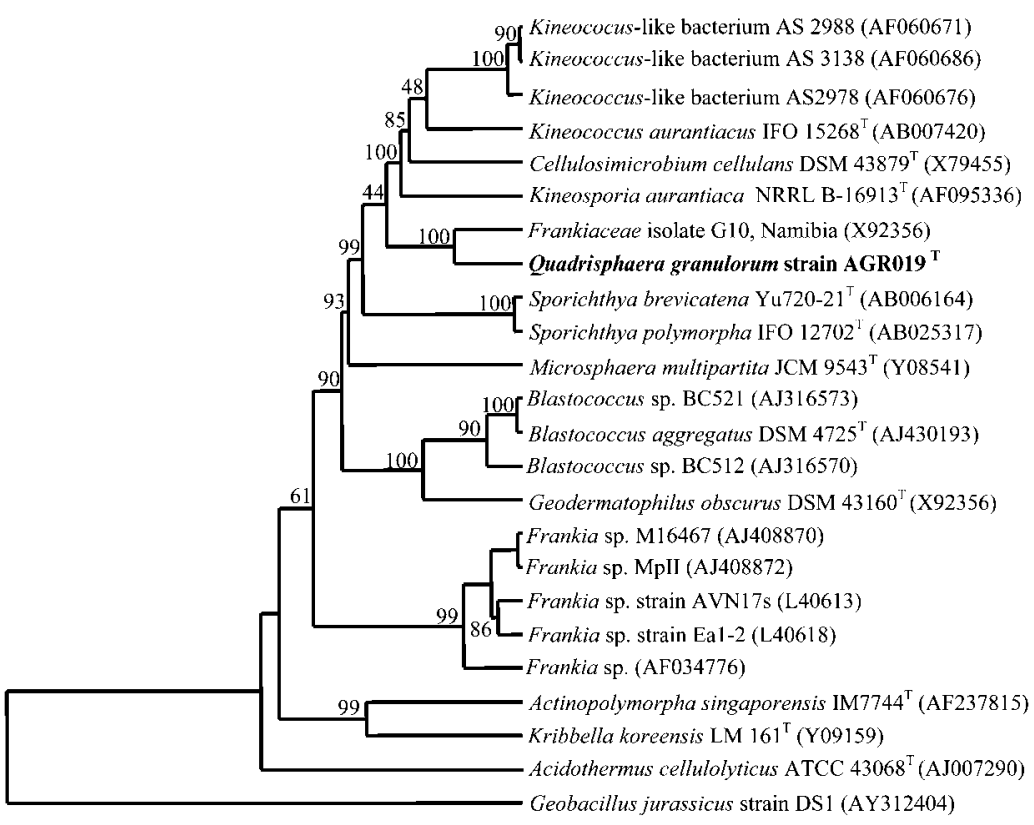

0.1
Fig. 2. Phylogenetic tree based on analysis of $16 \mathrm{~S}$ rRNA gene sequences of strain $A G 019^{\top}$ and representatives of the Actinobacteria. All sequences used in the analysis were obtained from GenBank. Bootstrap values, expressed as a percentage of 100 replications, are shown at the branching points. Bar, 10 substitutions per $100 \mathrm{nt}$. 
Actinobacteria group, which includes the genera Tessaracoccus (Maszenan et al., 1999a), Friedmanniella (Maszenan et al., 1999b) and Tetrasphaera (Maszenan et al., 2000).

Using the taxonomic scheme of Stackebrandt et al. (1997), it is clear that strain $\mathrm{AG} 019^{\mathrm{T}}$ fits readily within the suborder Frankineae, except that A-T is found instead of $\mathrm{G}-\mathrm{C}$ at nucleotide positions $127-234$, and that $\mathrm{A}-\mathrm{T}$ is present instead of G-C at positions 141-222 (see Table S1 available as supplementary data in IJSEM Online). The most closely related genera show complete concurrence with the scheme of Stackebrandt et al. (1997) for the suborder Frankineae. On the other hand, the 16S rRNA structure of strain AG019 ${ }^{\mathrm{T}}$ also contains several nucleotide pairs that are different from those of members of the families Frankiaceae, Geodermatophilaceae, Microsphaeraceae, Sporichthyaceae and Acidothermaceae (see Table S2 available as supplementary data in IJSEM Online), lending support to the notion that strain $\mathrm{AG} 019^{\mathrm{T}}$ belongs to a novel genus in the suborder Frankineae.

Strain AG019 ${ }^{\mathrm{T}}$ differs from the cells of the genus Frankia, which occur as chains of cocci, while Geodermatophilus and Blastococcus are pleomorphic and occur as rods and cocci. Sporichthya and Microsphaera, in the suborder Frankineae, are cocci. However, the cell-wall peptidoglycan of Sporichthya contains LL-diaminopimelic acid and the menaquinones MK-9 $\left(\mathrm{H}_{6}\right)$ and MK-9 $\left(\mathrm{H}_{8}\right)$ (Rainey et al., 1993), while strain $\mathrm{AG} 019^{\mathrm{T}}$ possesses meso-diaminopimelic acid and MK-8 $\left(\mathrm{H}_{2}\right)$ as its dominant menaquinones. Although strain $\mathrm{AG}_{019}{ }^{\mathrm{T}}$, members of the genus Kineococcus (Yokota et al., 1993; Phillips et al., 2002) and members of the genus Microsphaera (Yoshimi et al., 1996) contain meso-diaminopimelic acid in their cell-wall peptidoglycan, strain $\mathrm{AG} 019^{\mathrm{T}}$ has a major menaquinone profile that is different from that of Microsphaera and Kineococcus. Members of the genera Microsphaera and Kineococcus possess MK- $8\left(\mathrm{H}_{4}\right)$ and MK- $9\left(\mathrm{H}_{2}\right)$, respectively, whereas MK-8 $\left(\mathrm{H}_{2}\right)$ is the predominant quinone in strain $\mathrm{AG} 019^{\mathrm{T}}$.

Pairwise comparison of $16 \mathrm{~S}$ rRNA gene sequences revealed that strain $\mathrm{AG019^{ \textrm {T } }}$ was $95 \%$ similar to Kineococcus-like bacteria and Sporichthya, $93 \%$ similar to the type strain of Kineococcus aurantiacus, less than $94 \%$ similar to members of the genera Frankia and Blastococcus, and $93 \%$ similar to members of the genera Acidothermus, Geodermatophilus and Microsphaera (Fig. 2). These results, taken together with the phylogenetic analysis described earlier, show that strain $\mathrm{AG} 019^{\mathrm{T}}$ is different from members of the genera Frankia, Blastococcus, Microsphaera, Acidothermus, Sporichthya and Geodermatophilus (Table 2).

Strain $\mathrm{AG} 19^{\mathrm{T}}$ is only $97 \cdot 2 \%$ similar to its closest phylogenetic relative, strain G10, which originated from Namibia and which had been previously reported to be equidistantly related to Geodermatophilus obscurus, Frankia and Acidothermus cellulolyticus (Eppard et al., 1996). In this study, strains $\mathrm{AG} 019^{\mathrm{T}}$ and G10 form a coherent group.
However, on the basis of chemotaxonomic properties such as the presence of a greenish to dark pigment, faint glossy colonies and a reproduction mechanism involving binary fission and budding, as described by Eppard et al. (1996), strain G10 appears to be more closely related to the genus Geodermatophilus than to strain $\mathrm{AG} 019^{\mathrm{T}}$. Thus the phylogenetic evidence and chemotaxonomic properties presented so far support the placement of strain AG019 ${ }^{\mathrm{T}}$ in a novel genus, for which we propose the name Quadrisphaera, with Quadrisphaera granulorum as the type species.

\section{Description of Quadrisphaera gen. nov.}

Quadrisphaera (Qua.dri.sphae'ra. L. pref. numer. adj. quadr- four; L. fem. n. sphaera a ball, globe, sphere; N.L. fem. n. Quadrisphaera fourfold balls, coccus in tetrad).

Gram-positive, non-spore-forming cocci, $1 \cdot 2-3 \cdot 0 \mu \mathrm{m}$ in diameter, occuring in tetrad arrangement, fitting the morphological description of TFOs. MK- $8\left(\mathrm{H}_{2}\right)$ is the predominant menaquinone. The phylogenetic position is in the family Frankiaceae.

\section{The type species is Quadrisphaera granulorum.}

\section{Description of Quadrisphaera granulorum sp. nov.}

Quadrisphaera granulorum (gra.nu.lo'rum. L. gen. pl. neut. n. granulorum from, or of, granules).

Results obtained with the Biolog GN and GP systems and the API 20E system showed that strain AG019 ${ }^{\mathrm{T}}$ has the following characteristics (in addition to those described in the genus description). Utilizes $\alpha$-cyclodextrin, $\alpha$-DL-glycerol phosphate, Tween 40, arbutin, glucose 1-phosphate, Tween 80 , glucose 6-phosphate, adonitol, L-arabinose, D-arabitol, glucuronamide, cellobiose, D-psicose, D-mannitol, D-melezitose, D-melibiose, L-serine, methyl $\beta$-D-glucoside, psicose, D-xylose, methyl pyruvate, pyruvate, 2-aminoethanol, mono-methyl succinate, glycerol, L-serine, turanose and glycerol. Strain $\mathrm{AG} 019^{\mathrm{T}}$ cannot metabolize the following: $\beta$-cyclodextrin, dextrin, glycogen, inulin, mannan, $N$-acetyl D-galactosamine, $\mathrm{N}$-acetylglucosamine, $\mathrm{N}$-acetylmannosamine, amygdalin, D-arabitol, cellobiose, i-erythritol, Dfructose, L-fucose, D-galactose, D-galacturonic acid, gentiobiose, D-glucuronic acid, $\alpha$-D-glucose, $m$-inositol, $\alpha$ D-lactulose, $\alpha$-lactose, maltose, D-mannitol, D-mannose, Dmelezitose, methyl $\alpha$-D-galactoside, methyl $\beta$-D-galactoside, 3 -methyl glucose, methyl $\alpha$-D-glucoside, methyl $\beta$-Dglucoside, methyl $\alpha$-D-mannoside, palatinose, D-raffinose, L-rhamnose, salicin, sedoheptulosan, D-sorbitol, stachyose, sucrose, D-trehalose, xylitol, acetic acid, $\alpha$-hydroxybutyric acid, $\beta$-hydroxybutyric acid, $\gamma$-hydroxybutyric acid, $p$ hydroxyphenylacetic acid, $\alpha$-ketoglutaric acid, cis-aconitic acid, citric acid, formic acid, D-galactonic acid lactone, itaconic acid, malonic acid, quinic acid, D-saccharic acid, sebacic acid, lactamide, D-lactic acid methyl ester, D-malic acid, L-malic acid, propionic acid, succinamic acid, succinic 
Table 2. Comparative phenotypic characteristics of strain $A G 019^{\top}$ and members of the suborder Frankineae

All isolates are Gram-positive. Symbols: +, positive test result; -, negative test result; +/-, variable test result; ND, not determined.

\begin{tabular}{|c|c|c|c|c|c|c|c|}
\hline Phenotypic characteristic & Frankia* & Geodermatophilus* & Blastococcus $^{\star}$ & Microsphaera $\dagger$ & Sporichthya & Acidothermus $§$ & Strain AG019 ${ }^{T}$ \\
\hline $\mathrm{O}_{2}$ requirement & $\begin{array}{l}\text { Aerobic to } \\
\text { microaerophilic }\end{array}$ & Aerobic & $\begin{array}{l}\text { Aerobic to } \\
\text { microaerophilic }\end{array}$ & Aerobic & Aerobic & Aerobic & Aerobic \\
\hline Cell morphology & $\begin{array}{l}\text { Actinomycetes } \\
\text { producing } \\
\text { septate and } \\
\text { filamentous } \\
\text { mycelium }\end{array}$ & $\begin{array}{l}\text { Motile rods, } \\
\text { irregularly } \\
\text { shaped aggregates } \\
\text { of coccoid cells }\end{array}$ & $\begin{array}{l}\text { Motile rods, } \\
\text { irregularly shaped } \\
\text { aggregates of } \\
\text { coccoid cells }\end{array}$ & Cocci & $\begin{array}{l}\text { Aggregate of coccoid } \\
\text { cells in tetrad } \\
\text { arrangements }\end{array}$ & $\begin{array}{l}\text { Slender rods and } \\
\text { floccules }\end{array}$ & $\begin{array}{l}\text { Aggregates of } \\
\text { coccoid cells in } \\
\text { tetrad arrangements }\end{array}$ \\
\hline Motilityll &,- non-motile &,+ motile & - , non-motile & - , non-motile & $+1-$ & - , non-motile &,- non-motile \\
\hline Habitat & Soil, plant roots & Desert soil, sea & Sea & $\begin{array}{l}\text { Sugar waste } \\
\text { activated } \\
\text { sludge }\end{array}$ & Soil & Hot spring & $\begin{array}{l}\text { Aerobic granular } \\
\text { sludge }\end{array}$ \\
\hline $\begin{array}{l}\text { Optimum growth } \\
\text { temperature }\left({ }^{\circ} \mathrm{C}\right)\end{array}$ & $20-36$ & 26 & ND & 25 & $20-30$ & $50-60$ & 37 \\
\hline Optimum growth $\mathrm{pH}$ & ND & ND & ND & $7 \cdot 0$ & ND & $5 \cdot 0$ & $7 \cdot 5$ \\
\hline $\begin{array}{l}\text { Growth temperature } \\
\text { range }\left({ }^{\circ} \mathrm{C}\right)\end{array}$ & $10-37$ & $10-37$ & $\mathrm{ND}$ & $10-35$ & $15-37$ & $37-70$ & $15-40$ \\
\hline Growth $\mathrm{pH}$ range & $6 \cdot 4-6 \cdot 8$ & ND & ND & $5 \cdot 0-9 \cdot 0$ & ND & $3 \cdot 5-7 \cdot 0$ & $5 \cdot 0-9 \cdot 0$ \\
\hline Oxidase & $\mathrm{ND}$ & ND & ND & - & $\mathrm{ND}$ & - & - \\
\hline Catalase & + & + & $\mathrm{ND}$ & + & $\mathrm{ND}$ & + & + \\
\hline Cell-wall type & $\begin{array}{l}\text { meso-Diaminopimelic } \\
\text { acid (type III) } \mathbf{9} \\
\text { lacks mycolic acid }\end{array}$ & $\begin{array}{l}\text { meso-Diaminopimelic } \\
\text { acid (type III); lacks } \\
\text { mycolic acid }\end{array}$ & ND & $\begin{array}{l}\text { meso-Diaminopimelic } \\
\text { acid }\end{array}$ & $\begin{array}{l}\text { LL-Diaminopimelic } \\
\text { acid }\end{array}$ & $\begin{array}{l}\text { meso-Diaminopimelic } \\
\text { acid }\end{array}$ & $\begin{array}{l}\text { meso-Diaminopimelic } \\
\text { acid; lacks } \\
\text { mycolic acid }\end{array}$ \\
\hline Major menaquinone & MK-9 $\left(\mathrm{H}_{4}\right)$ & MK-9 $\left(\mathrm{H}_{4}\right)$ & ND & MK-8 $\left(\mathrm{H}_{4}\right)$ & MK-9 $\left(\mathrm{H}_{6}\right)$, MK- $9\left(\mathrm{H}_{8}\right)$ & ND & MK-8 $\left(\mathrm{H}_{2}\right)$ \\
\hline Polar lipid(s)\# & PIM, PI, DPG & PII & $\mathrm{ND}$ & $\mathrm{ND}$ & PI, PG, DPG & ND & DPG, PG, PI \\
\hline Nitrate reduction & ND & $+1-$ & ND & ND & + & - & - \\
\hline DNA G $+\mathrm{C}$ content $(\mathrm{mol} \%)$ & $66-71$ & $73-75$ & $70-75$ & 68 & $70-71$ & 61 & 75 \\
\hline
\end{tabular}

${ }^{*}$ Normand et al. (1996).

$\dagger$ Yoshimi et al. (1996).

‡Rainey et al. (1993), Tamura et al. (1999).

\$Mohagheghi et al. (1986).

IINote: Sporichthya brevicatena spores exhibit motility when suspended in sterile distilled water.

Type III cell walls contain meso-diaminopimelic acid, which contains glutamic acid, alanine, glucosamine and muramic acid.

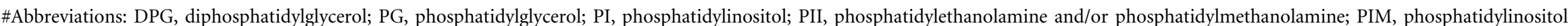
mannosides. 
acid, $\mathrm{N}$-acetylglutamic acid, bromosuccinic acid, alaninamide, D-alanine, L-alanine, L-alanyl-glycine, L-asparagine, glycyl-L-glutamic acid, L-pyroglutamic acid, putrescine, 2,3butanediol, glycyl-L-aspartic acid, L-histidine, hydroxyl-Lproline, L-leucine, L-ornithine, L-phenylalanine, L-proline, L-pyroglutamic acid, D-serine, L-threonine, DL-carnitine, $\gamma$ aminobutyric acid, adenosine, $2^{\prime}$-deoxyadenosine, inosine, thymidine, uridine, adenosine $5^{\prime}$-monophosphate, thymidine $5^{\prime}$-monophosphate, uridine $5^{\prime}$-monophosphate, phenylethylamine or putrescine. The following acid and acid derivatives are utilized by strain $\mathrm{AG} 019^{\mathrm{T}}$ : glucuronic acid, $\alpha$ ketobutyric acid, $\alpha$-ketovaleric acid, DL-lactic acid, Laspartic acid, L-glutamic acid, uroconic acid and pyruvic acid. The enzyme activities detected by both API ZYM and API 20E are as follows: esterase, esterase lipase, leucine arylamidase, valine arylamidase, naphthol-AS-BIphosphohydrolase, $\beta$-galactosidase, $\alpha$-glucosidase and $\beta$ glucosidase. Activities of the following enzymes are not detected by API ZYM: alkaline phosphatase, lipase, cystine arylamidase, trypsin, chymotrypsin, acid phosphatase, $\alpha$ galactosidase, $\beta$-glucuronidase, $N$-acetyl- $\beta$-glucosaminidase, $\alpha$-mannosidase and $\alpha$-fucosidase. Activities of the following enzymes are not detected by API 20E: arginine dihydrolase, lysine decarboxylase, ornithine decarboxylase, urease, tryptophan deaminase and gelatinase. Strain AG019 ${ }^{\mathrm{T}}$ does not produce $\mathrm{H}_{2} \mathrm{~S}$ or indole. It is VogesProskauer-negative, does not produce acetoin and does not reduce nitrate to nitrite. It is catalase-positive but oxidasenegative. The genomic $\mathrm{G}+\mathrm{C}$ content is $75 \mathrm{~mol} \%$.

The type strain, AG019 ${ }^{\mathrm{T}}\left(=\mathrm{ATCC}\right.$ BAA- $1104^{\mathrm{T}}=\mathrm{DSM}$ $44889^{\mathrm{T}}$ ), was isolated from aerobic granules.

\section{Acknowledgements}

We thank Professor H. Trüper for his assistance in naming the organism.

\section{References}

Altschul, S. F., Madden, T. L., Schaffer, A. A., Zhang, J., Zhang, Z., Miller, W. \& Lipman, D. J. (1997). Gapped BLAST and PSI-BLAST: a new generation of protein database search programs. Nucleic Acids Res 25, 3389-3420.

Buck, J. D. (1982). Non-staining (KOH) method for determination of Gram reactions of marine bacteria. Appl Environ Microbiol 44, 992-993.

Cech, J. S. \& Hartman, P. (1990). Glucose induced breakdown of enhanced biological phosphate removal. Environ Technol 11, 651-656.

Cech, J. S., Hartman, P. \& Macek, M. (1994). Bacteria and protozoa population dynamics in biological phosphate removal systems. Water Sci Technol 29, 109-117.

Christensson, M., Blackall, L. L. \& Welander, T. (1998). Metabolic transformations and characterization of the sludge community in an enhanced biological phosphorus removal system. Appl Microbiol Biotechnol 49, 226-234.
Dulekgurgen, E., Ovez, S., Artan, N. \& Orhon, D. (2003). Enhanced biological phosphate removal by granular sludge in a sequencing batch reactor. Biotechnol Lett 25, 687-693.

Eppard, M., Krumbein, W. E., Koch, C., Rhiel, E., Staley, J. T. \& Stackebrandt, E. (1996). Morphological, physiological, and molecular characterization of actinomycetes isolated from dry soil, rocks, and monument surfaces. Arch Microbiol 166, 12-22.

Felsenstein, J. (1985). Confidence limits of phylogenies: an approach using the bootstrap. Evolution 39, 783-791.

Hall, T. (1997). BioEdit. Biological sequence alignment editor for Win 95/98/NT/2K/XP. Carlsbad, CA: Ibis Therapeutics.

Jang, A., Yoon, Y.-H., Kim, I. S., Kim, K.-S. \& Bishop, P. L. (2003). Characterization and evaluation of aerobic granules in sequencing batch reactor. J Biotechnol 105, 71-82.

Jiang, H.-L., Tay, J.-H. \& Tay, S. T.-L. (2002). Aggregation of immobilized activated sludge cells into aerobically grown microbial granules for the aerobic biodegradation of phenol. Lett Appl Microbiol 35, 439-445.

Jiang, H.-L., Tay, J.-H. \& Tay, S. T.-L. (2004). Changes in structure, activity and metabolism of aerobic granules as a microbial response to high phenol loading. Appl Microbiol Biotechnol 63, 602-608.

Lin, Y.-M., Liu, Y. \& Tay, J. H. (2003). Development and characteristics of phosphorus-accumulating microbial granules in sequencing batch reactors. Appl Microbiol Biotechnol 62, 430-435.

Maidak, B. L., Olsen, G. J., Larsen, N., Overbeek, R., McCaughey, M. J. \& Woese, C. R. (1997). The RDP (Ribosomal Database Project). Nucleic Acids Res 25, 109-111.

Malik, A., Sakamoto, M., Hanazaki, S., Osawa, M., Suzuki, T., Tochigi, M. \& Kakii, K. (2003). Coaggregation among nonflocculating bacteria isolated from activated sludge. Appl Environ Microbiol 69, 6056-6063.

Maszenan, A. M. (2000). The occurrence, characterization and biodiversity of "G-bacteria" in activated sludge systems. $\mathrm{PhD}$ thesis, La Trobe University.

Maszenan, A. M., Seviour, R. J., Patel, B. K. C., Rees, G. N. \& McDougall, B. M. (1997). Amaricoccus gen. nov., a Gram-negative coccus occurring in regular packages or tetrads isolated from activated sludge biomass, and descriptions of Amaricoccus veronensis sp. nov., Amaricoccus tamworthensis sp. nov., Amaricoccus macauensis sp. nov., and Amaricoccus kaplicensis sp. nov. Int J Syst Bacteriol 47, 727-734.

Maszenan, A. M., Seviour, R. J., Patel, B. K. C., Schumann, P. \& Rees, G. N. (1999a). Tessaracoccus bendigoensis gen. nov., sp. nov., a Gram-positive coccus occurring in regular packages or tetrads, isolated from activated sludge biomass. Int J Syst Bacteriol 49, 459-468.

Maszenan, A. M., Seviour, R. J., Patel, B. K. C., Schumann, P., Burghardt, J., Webb, R., Soddell, J. A. \& Rees, G. N. (1999b). Two Gram-positive cocci growing in aggregates of repeating groups of cocci isolated from activated sludge foam belong to the genus Friedmanniella as new species, Friedmanniella spumicola sp. nov. and Friedmanniella capsulata sp. nov. Int J Syst Bacteriol 49, 1667-1680.

Maszenan, A. M., Seviour, R. J., Patel, B. K. C., Schumann, P., Burghardt, J., Tokiwa, Y. \& Stratton, H. M. (2000). Three isolates of novel polyphosphate-accumulating Gram-positive cocci, obtained from activated sludge, belong to a new genus, Tetrasphaera gen. nov., and description of two new species, Tetrasphaera japonica sp. nov. and Tetrasphaera australiensis sp. nov. Int J Syst Evol Microbiol 50, 593-603.

Mohagheghi, A., Grohmann, K., Himmel, M., Leighton, L. \& Updegraff, D. M. (1986). Isolation and characterization of Acidothermus cellulolyticus gen. nov., sp. nov., a new genus of 
thermophilic, acidophilic, cellulolytic bacteria. Int J Syst Bacteriol 36, 435-443.

Moy, B. Y. P., Tay, J. H., Toh, S. K., Liu, Y. \& Tay, S. T.-L. (2002). High organic loading influences the physical characteristics of aerobic sludge granules. Lett Appl Microbiol 34, 407-412.

Normand, P., Orso, S., Cournoyer, B., Jeannin, P., Chapelon, C., Dawson, J., Evtushenko, L. \& Misra, K. (1996). Molecular phylogeny of the genus Frankia and related genera and emendation of the family Frankiaceae. Int J Syst Bacteriol 46, 1-9.

Pan, S., Tay, J. H., He, Y. X. \& Tay, S. T. L. (2004). The effect of hydraulic retention time on the stability of aerobically grown microbial granules. Lett Appl Microbiol 38, 158-163.

Phillips, R. W., Wiegel, J., Berry, C. J., Fliermans, C., Peacock, A. D., White, D. C. \& Shimkets, L. J. (2002). Kineococcus radiotolerans sp. nov., a radiation-resistant, Gram-positive bacterium. Int J Syst Evol Microbiol 52, 933-938.

Rainey, F. A., Schumann, P., Prauser, H., Toalster, R. \& Stackebrandt, E. (1993). Sporichthya polymorpha represents a novel line of descent within the order Actinomycetales. FEMS Microbiol Lett 109, 263-269.

Rees, G. N., Vasiliadis, G., May, J. W. \& Bayly, R. C. (1992). Differentiation of polyphosphate and poly- $\beta$-hydroxybutyrate granules in an Acinetobacter sp. isolated from activated sludge. FEMS Microbiol Lett 94, 171-174.

Schleifer, K. H. \& Kandler, O. (1972). Peptidoglycan types of bacterial cell walls and their taxonomic implications. Bacteriol Rev 36, 406-477.

Schumann, P., Prauser, H., Rainey, F. A., Stackebrandt, E. \& Hirsch, P. (1997). Friedmanniella antarctica gen. nov., sp. nov., an LLdiaminopimelic acid-containing actinomycete from Antarctic sandstone. Int J Syst Bacteriol 47, 278-283.

Seviour, R. J., Maszenan, A. M., Soddell, J. A., Tandoi, V., Patel, B. K. C., Kong, Y.-H. \& Schumann, P. (2000). Microbiology of the "G-bacteria" in activated sludge. Environ Microbiol 2, 1-14.

Skerman, V. B. D. (1968). A new type of micromanipulator and microforge. J Gen Microbiol 54, 287-297.

Smibert, R. M. \& Krieg, N. L. (1994). Phenotypic characterization. In Methods for General and Molecular Bacteriology, pp. 607-654. Edited by P. Gerhardt, R. G. E. Murray, W. A. Wood \& N. R. Krieg. Washington, DC: American Society for Microbiology.

Stackebrandt, E., Rainey, F. A. \& Ward-Rainey, N. L. (1997). Proposal for a new hierarchic classification system, Actinobacteria classis nov. Int J Syst Bacteriol 47, 479-491.

Tamura, T., Hayakawa, M. \& Hatano, K. (1999). Sporichthya brevicatena sp. nov. Int J Syst Bacteriol 49, 1779-1784.

Tay, J.-H., Liu, Q.-S. \& Liu, Y. (2001). Microscopic observation of aerobic granulation in sequential aerobic sludge reactor. $J$ Appl Microbiol 91, 168-175.

Tay, J.-H., Yang, S.-F. \& Liu, Y. (2002). Hydraulic selection pressureinduced nitrifying granulation in sequencing batch reactors. Appl Microbiol Biotechnol 59, 332-337.

Thompson, J. D., Higgins, D. G. \& Gibson, T. J. (1994). CLUSTAL W: improving the sensitivity of progressive multiple sequence alignment through sequence weighting, position-specific gap penalties and weight matrix choice. Nucleic Acids Res 22, 4673-4680.

Tsai, C.-S. \& Liu, W.-T. (2002). Phylogenetic and physiological diversity of tetrad-forming organisms in deteriorated biological phosphorus removal systems. Water Sci Technol 46, 179-184.

Williams, T. M. \& Unz, R. F. (1985). Isolation and characterization of filamentous bacteria present in bulking activated sludge. Appl Microbiol Biotechnol 22, 273-282.

Winker, S. \& Woese, C. R. (1991). A definition of the domains Archaea, Bacteria, and Eucarya in terms of small ribosomal RNA characteristics. Syst Appl Microbiol 14, 305-310.

Yokota, A., Tamura, T., Nishil, T. \& Hasegawa, T. (1993). Kineococcus aurantiacus gen nov., sp. nov., a new aerobic Gram-positive, motile coccus with meso-diaminopimelic acid and arabinogalactan in the cell wall. Int J Syst Bacteriol 43, 52-57.

Yoshimi, Y., Hiraishi, A. \& Nakamura, K. (1996). Isolation and characterization of Microsphaera multipartita gen. nov., sp. nov., a polysaccharide-accumulating Gram-positive bacterium from activated sludge. Int J Syst Bacteriol 46, 519-525.

Zeng, R. J., Saunders, A. M., Yuan, Z.-G., Blackall, L. L. \& Keller, J. (2003). Identification and comparison of aerobic and denitrifying polyphosphate-accumulating organisms. Biotechnol Bioeng 83, $140-148$. 